\title{
Purchase Behaviour in Advergame and the Effect of Brand Attitude as a Mediator
}

\author{
Azaze-Azizi Abdul Adis ${ }^{1}$, Hyung-Jun Kim², Mohd Rizwan Abdul Majid ${ }^{1}$, Zaiton Osman ${ }^{1}$, Izyanti Awang Razli ${ }^{1}$ \\ $\&$ Grace Phang Ing ${ }^{1}$ \\ ${ }^{1}$ Faculty of Business, Economics \& Accountancy, Universiti Malaysia Sabah, Kota Kinabalu, Malaysia \\ ${ }^{2}$ College of Business Administration \& Economics, Chungnam National University, Daejeon, Republic of Korea \\ Correspondence: Azaze-Azizi Abdul Adis, Faculty of Business, Economics \& Accountancy, Universiti Malaysia \\ Sabah, Jalan UMS, 88400, Kota Kinabalu, Sabah, Malaysia. Tel: 60-88-32-0000. E-mail: azizi@ums.edu.my
}

Received: October 27, 2014 Accepted: November 25, 2014 Online Published: February 12, 2015

doi:10.5539/ass.v11n5p249 URL: http://dx.doi.org/10.5539/ass.v11n5p249

\begin{abstract}
In this paper, we examine the impact of self-brand congruity and entertainment factors in influencing brand attitude among gamers on advergame. The role of brand attitude in mediating the relationship between self-brand congruity and entertainment on purchase intention is also examined. By using structural equation modelling (SEM), the results show that self-brand congruity and entertainment influenced brand attitude and purchase intention in advergame. As expected, brand attitude plays a crucial role in mediating the relationship between self-brand congruity and entertainment on purchase intention. This study also suggests some implications and directions for future research.
\end{abstract}

Keywords: advergame, self-brand congruity, entertainment, brand attitude, purchase intention

\section{Introduction}

Brand attitude by definition is either a positive or negative judgment of individual's feeling toward a brand (Shimp, 2000) and consists of a cognitive, affective and conative component (Lutz, 1977). In addition, brand attitude can also be associated with becoming a necessary communication effect when the brand purchase occurred (Percy \& Rossiter, 1992). In advergame, research on brand attitude toward purchase intention had showed remarkable progress in contributing to the theory of buyer behaviour (Abdul Adis \& Kim, 2013a; 2013b; Gross, 2010; Cauberghe \& Pelsmacker, 2010; Lee \& Faber, 2007; Nelson, Keum, \& Yaros, 2004; Nelson, 2002).

Game produces high levels of emotion and excitement (Fiore, Jin, \& Kim, 2005) which provide a platform for the realistic magnification of the internal-self (Childers, Carr, Peck, \& Carson, 2001; Scarpi, 2012). In conjunction, consumer self-concept research is still in early phase than consumer attitude research (Sirgy, 1985), contributes to more issue pertaining self-concept and consumer attitude which are still unanswered. Davis, Lang \& Gautam, (2013) and Davis \& Lang (2013) for example, investigated the influence of self-congruity on purchase usage of games. Although these studies successfully confirmed the impact of self-congruity and game purchase and usage, none of them focused on the effects of self-brand congruity on gamers' attitude towards advertisement which appeared in the games they played. These effects will be investigated in this study. This is vital for the advertisers to comprehend the positive and negative impact of self-brand congruity on consumer responses when and after playing games.

Nowadays, the aggressiveness of the internet advertising encourages advertisers to be more creative, targeted and effective (Mangalindan, Swisher, Bank, Hamilton \& Clark, 2004). Entertainment is an important principle when using interactive and digital media (Taylor, 2009). Therefore, the element of 'enjoyment' always was emphasized by the advertisers in their advertising strategy in games. Due to this, entertainment value is also considered in this study as one of the factor not to be ignored in examining brand attitude in advergames.

\subsection{How Self-Brand Congruity Can Influence Brand Attitude and Purchase Intention?}

Previous studies on consumer behavior has established that constructs such as brand attitude, brand preference, brand choice, purchase motivation, purchase intention, brand purchase, brand satisfaction, and brand loyalty have positive influence on actual self-congruity (see Sirgy, Lee, Johar, \& Tidwell, 2008; Sirgy, 1985; Sirgy, Grewal, \& Mangleburg, 2000; Sirgy \& Su, 2000; Lui, Li, Mizerski, \& Soh, 2012; Hohenstein, Sirgy, Herrmann, 
\& Heitmann, 2007). One of earlier scholars in self-images research, Dolich (1969) conducted a research with the purpose to examine whether products were perceived as symbols and organized into congruent relationships with the self-concept. The results revealed that individuals tended to relate the brand symbol to self-concepts with greater similarity with brand most preferred images.

Self-brand congruity can be conceptualized as the match between a brand's value-expressive attributes (e.g., product/ user images) and the consumer or user's image of self (Sirgy, 1985). Subsequently, there were inspiring studies in discussing the association between self-congruity and purchase intention. Prominent scholar found that self-congruity significantly influence purchase intention (Sirgy, 1985). Internal self-congruity was found as an crucial feature in expediting greater attitudinal acceptance of advertisements designed to appear in the Social Network Services context (Taylor, Lewin, \& Strutton, 2011). They assumed that consumers often associates the images they portray about themselves with the image that had been associated with a brand. The greater the congruity, the more positive the consumer's attitude was towards the brand (Escalas \& Bettman, 2005). In event sponsorship, that self-congruity with a sponsorship event had a positive influence on brand loyalty when customers were aware of the firm sponsoring the event and when it has an association with the event (Sirgy et al., 2008). These findings showed the importance of self-congruity in determining brand attitude.

This paper extends the self-concept model by Sirgy (1985) on self-concept factors i.e., self-congruity and ideal congruity as antecedents towards purchase motivation. Self-congruity is defined as a congruity between the actual self-image and the product image while ideal congruity is defined as a congruity between the ideal self-image and product image (Sirgy, 1985).

A recent study by Davis et al. (2013) to model the relationship between hedonic and utilitarian consumption in the purchase and use of games provided interesting findings regarding self-concept, self-congruity and self-efficacy of hedonic consumption. They concluded that hedonic had positive impacts on game purchase and usage than utilitarian consumption. They also suggested that utilitarian consumption had an indirect causal effect on game purchase or usage through hedonic consumption. Moreover, according to Fiore et al., (2005) games craft pleasurable emotion and excitement and self-congruity was important in the context of a game due to its influence on imagination and experience (Davis et al., 2013). Gamers always looked a significant gap in the congruity between their own actual self-concept and the ideal self. Therefore, we propose two hypotheses:

H1: There is positive influence of self-brand congruity on brand attitude.

H2: There is positive influence of self-brand congruity on consumer's purchase intention.

1.2 How Entertainment Can Influence Brand Attitude and Purchase Intention?

In advertising research, Ducoffe (1995) introduced new construct of advertising value which consisted of perceived informativeness, perceived entertainment, and perceived irritation. These constructs were consistent measurement criteria and perceptual antecedents that measured user attitudes toward messages that were communicated through the traditional media such as TV commercials and magazine advertising. Ducoffe (1995) categorised the perceived behaviours into two categories, positive and negative. It was found that both perceived informativeness and perceived entertainment of an advertisement produced significant positive impact on attitude towards advertising, while perceived irritation provided negative impact. Ducoffe (1996) also concluded that advertising value were distinct and important antecedents of consumer attitudes.

Entertainment is a component of internet advertising. Internet advertising is more aggressive than previous forms of advertising; advertisers strived to be more creative, targeted and effective (Mangalindan et al., 2004). From the advertiser's perspective, entertainment is an important principle when using interactive and digital media (Taylor, 2009). Gamers appreciate and perceive entertainment aspects of an advergame that of a high value and importance. If a commercial is able to produce and fulfil the needs for escapism, diversion, aesthetic enjoyment, or emotional release, this commercial is said to be of a value appreciated by gamers as reported by uses and gratification research (Ducoffe, 1996). Moreover, similar research also found a significant positive relationship between entertainment and advertising value in traditional media and in web advertising (Ducoffe, 1995 \& 1996).

In the current research, entertainment can be defined as an entertainment value included in the game in order to influence user's attention to stay longer and spend more time in playing game. This can be referred as fun and enjoy environment created in the game in order to enhance the game entertainment attributes. In purchase behaviour, consumers not only purchased toys, but were also entertained while in the store. This would make consumers' purchasing experiences extend to complementary entertainment, which may keep them in the store longer and stimulate sales (Kim, Sullivan, \& Forney, 2007). Therefore, we propose:

H3: There is a positive influence of entertainment on brand attitude. 


\section{H4: There is a positive influence of entertainment on consumer's purchase intention.}

\subsection{The Association between Brand Attitude and Purchase Intention and Its Role as Mediator}

Brand attitude had been proved to have a positive impact on purchasing intention of customers (Shah, Aziz, Jaffari, Waris, Ejaz, Fatima, \& Sherazi, 2012; Teng \& Huihuang, 2007; Shwu-Lng \& Chen-Lien, 2009). In advergame, the change in brand attitude yield to game enjoyment was found stronger for product relevant with advergames (Wise, Bolls, Kim, Venkataraman, \& Meyer, 2008). Furthermore, brand attitude was seen as reflecting an interaction between a potential consumer's involvement with the purchase decision and the underlying motivation to purchase (Percy \& Rossiter, 1992). This supported the prediction that brand attitude may affect consumer behaviour during game playing.

\section{H5: There is a positive association between brand attitude and purchase intention.}

This study is based on brand attitude model developed by MacKenzie, Lutz \& Belch (1986)'s on "brand-related cognitions $\left(\mathrm{C}_{\mathrm{b}}\right) \rightarrow$ brand attitudes $\left(\mathrm{A}_{\mathrm{b}}\right) \rightarrow$ purchase intention $(\mathrm{PI})$ " and the "ad-related cognitions $\left(\mathrm{C}_{\mathrm{ad}}\right) \rightarrow$ attitude toward advertising $\left(\mathrm{A}_{\mathrm{ad}}\right)$ " linkages which is based on cognitive response model (please refer Figure 1). The study suggested four alternative causal models to explicate the mediating effects of attitude toward advertising $\left(\mathrm{A}_{\mathrm{ad}}\right)$ on brand attitude $\left(\mathrm{A}_{\mathrm{b}}\right)$ and purchase intention (PI). The first one is affect transfer hypothesis (ATH) which suggests that $A_{a d}$ exerts a one-way influence on $A_{b}$. The dual mediation hypothesis (DMH) specifies that $A_{a d}$ has a direct effect on $A_{b}$ and an indirect effect on $A_{b}$ through brand cognition $\left(C_{b}\right)$. The reciprocal mediation hypothesis (RMH) indicates an interactive relationship between $A_{a d}$ and $A_{b}$. The fourth, the independent influences hypothesis (IIH), assumes no causal relationship between $A_{a d}$ and $A_{b}$, and instead $A_{a d}$ will be an independent determinant of purchase intention (Huang, Su, Zou, \& Liu, 2013). According to MacKenzie et al. (1986), DMH is the most robust fit to their experimental data. The model provides a useful framework for considering brand placement and its ability to influence brand attitudes in advergames.

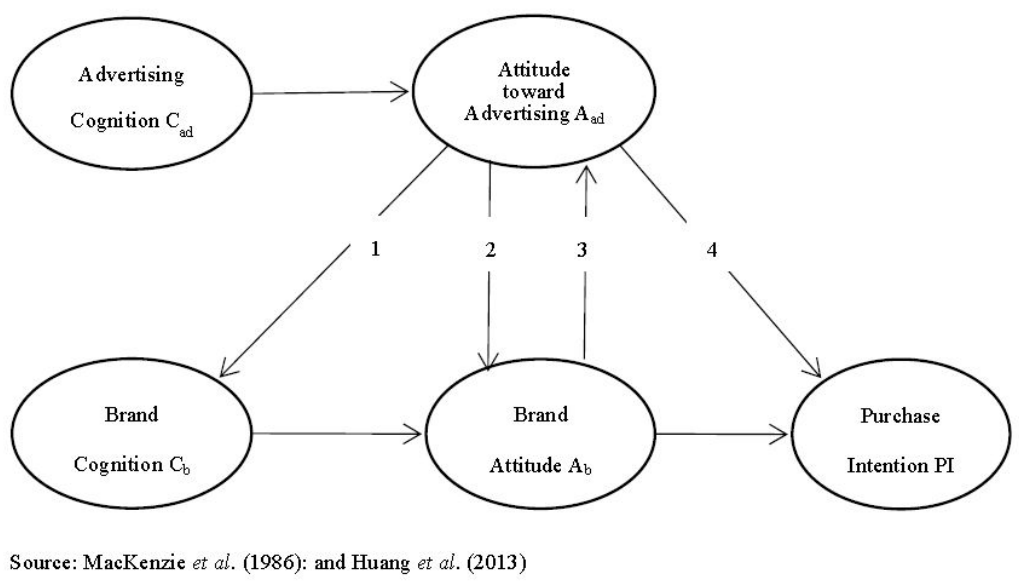

Figure 1. The labeled linkage exists when the following hypothesis is verified: Affect Transfer Hypothesis (ATH): 2; Dual Mediation Hypothesis (DMH): 1, 2 Reciprocal Mediation (RMH): 2, 3; Independent Influences Hypotheses (IIH): 4.

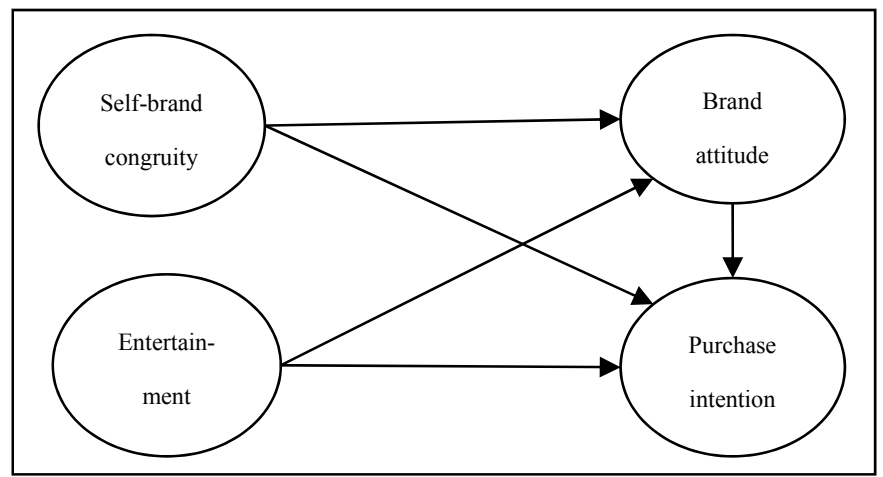

Figure 2. The mediating role of brand attitude between self-brand congruity, entertainment and purchase intention 
In this study, it is expected that brand attitude mediate the influence of self-brand congruity and entertainment on purchase intention as illustrate in Figure 2. As a mediating role, attitude toward the advertisement has received increasing attention as a mediator of advertising effects (Lutz, MacKenzie, \& Belch, 1983). A recent study on the impact of event marketing on brand equity by Zarantonello \& Schmitt (2012), only for certain types of events, brand attitudes was reported to mediated the relationship between events and brand equity. Therefore:

H6: The relationship between self-brand congruity and purchase intention is mediates by brand attitude.

H7: The relationship between entertainment and purchase intention is mediates by brand attitude.

\section{Research Method}

This study's scope includes self-brand congruity, entertainment, brand attitude and purchase intention in advergames. Brand attitude is also used as a mediator in this study. The sample for this study was collected through an online survey of gamers in Malaysia. The respondents were contacted and asked whether they were playing video, mobile, or SNS games. Then, respondents were guided to click on a link to an online questionnaire. If they did not play games, respondents were asked to refer their game-playing friends to participate in this study. A total of three hundred and sixty six respondents participated in this study. They were contacted through email and social network such as facebook. Approximately seventy four percent of the respondents habitually played games between one to eight hours per week (see Table 1).

For this study, a structured online survey questionnaire was designed. There were several reasons for using a survey in this study. First, this study attempted to test a natural viewing environment without using artificial stimuli to test consumer attitude. Respondents were asked whether they had experienced in-game advertisements during game playing. Second, using an online survey saved the respondent's time in answering the questions. For example, a test was conducted to compare the time spent between online and offline surveys. The results showed that compared with offline surveys, online surveys saved almost half the respondent's time in completing the questionnaires (Adis \& Kim, 2013).

Table 1. Respondent's profile

\begin{tabular}{llc}
\hline Profile & & $\mathrm{N}=366$ \\
\hline Gender & Male & 177 \\
& Female & 189 \\
Age & $19-20$ years & 47 \\
& $21-25$ years & 171 \\
& $26-30$ years & 95 \\
Time spend & $>30$ years & 53 \\
(hours in a week) & $<1$ hour & 16 \\
& $1-8$ Hours & 271 \\
Game mode & $>8$ hours & 79 \\
& Single player & 265 \\
Preferred game & Multiple player & 101 \\
& Free game & 349 \\
Type of game & Paid game & 17 \\
& Video game & 121 \\
& Mobile game & 134 \\
& SNS game (e.g. facebook, twitter) & 111 \\
\hline
\end{tabular}

\section{Results}

\subsection{Measurement Model Testing}

Confirmatory factor analysis (CFA) was conducted to examine the validity of the measurement model. The overall fit of the CFA and structural models were examined using common parameters, namely, chi-square statistics, goodness-of-fit index (GFI), comparative fit index (CFI), and root mean square error of approximation (RMSEA) (Hair, Black, Babin, Anderson, \& Tatham, 2006). The model fit the data relatively well (Table $2 \&$ Figure 3). From the goodness of-fit indices $\left(\mathrm{X}^{2}=67.685, \mathrm{df}=29, \mathrm{p}=.000, \mathrm{GFI}=.934, \mathrm{NFI}=.971, \mathrm{CFI}=.983\right.$, RMSEA $=.060$ ). Therefore, the result suggested that hypothesized model fitted the empirical data well. 
Table 2. Summary of Cronbach's Alpha, Factor Loading, Average Variance Extracted, and Composite Reliability

Factor/Items

\begin{tabular}{cccc} 
Cronbach's & Standardized & Average & Composite \\
Alpha & Factor & Variance & Loading \\
& Extracted & Reliability \\
\hline
\end{tabular}

.783

$$
.744
$$

0.642

0.841

$\mathrm{SBC} 2$ : The brands advertised through games cater to people like me.

SBC4: The typical customers of brands advertised through games are very much like me

\section{Entertainment}

ENT1: The brand you saw in game is attractive.

ENT2: The brand you saw in game is entertaining.

\section{Brand attitude}

ATT1: The brand you saw in the game is bad/good.

ATT2: The brand you saw in the game is lovable/not lovable.

\section{Purchase intention}

PI1: I would purchase brands I have seen in games

PI3: I started using brands after seeing them in games.

PI5: I buy brand when I see characters have been using in games.

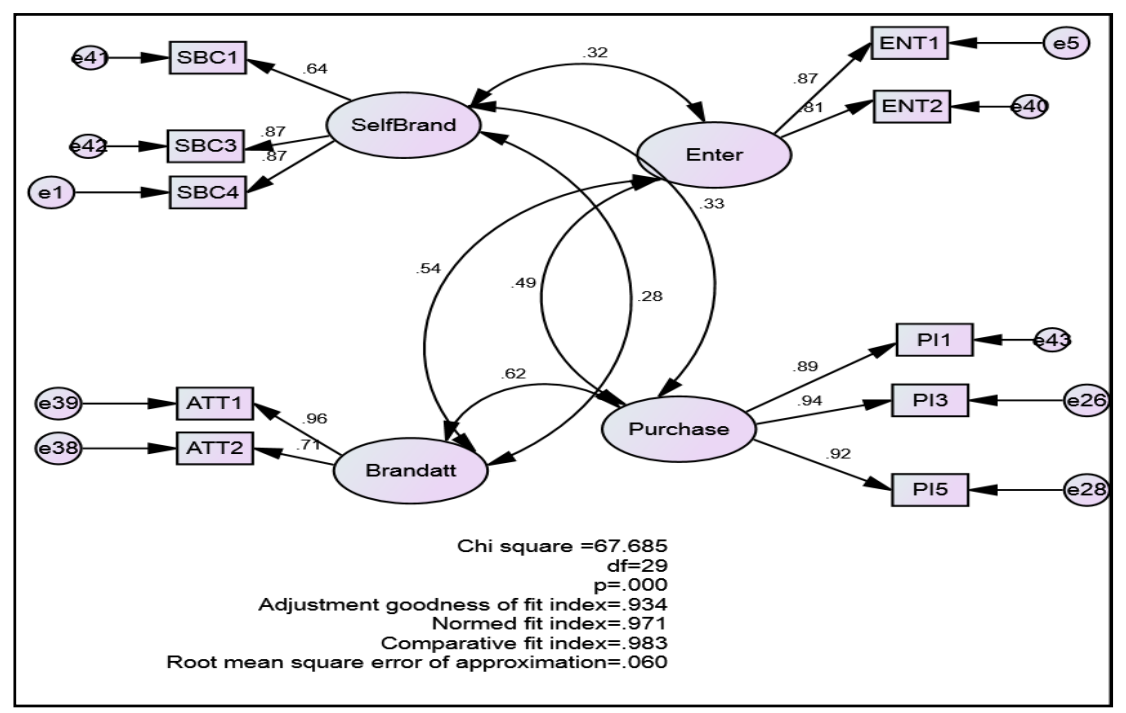

Figure 3. The empirical results of brand attitude and purchase behaviour model with parameter estimate

\subsection{Hypothesis Testing}

The proposed hypotheses of the study were tested using a series of simultaneous regression analysis and bootstrap analysis using structural equation modeling (SEM) with maximum likelihood estimation. Within the overall model, the estimates of the structural coefficients provided the basis for testing the proposed hypotheses. Based on Figure 4, there were positive relationships between self-brand congruity $\rightarrow$ brand attitude (H1), 
self-brand congruity $\rightarrow$ purchase intention (H2), entertainment $\rightarrow$ brand attitude (H3), entertainment $\rightarrow$ purchase intention (H4), and brand attitude $\rightarrow$ purchase intention (H5). Therefore H1, H2, H3, H4 and H5 were supported in this study. The results were summarized in Table 3.

Table 4 demonstrates the results of direct and indirect effects of self-brand congruity and entertainment on purchase intention through brand attitude as mediator. It was showed that brand attitude plays as significant mediator for self-brand congruity and entertainment in influencing purchase intention in advergames. The table shows that self-brand congruity has significant indirect effect on purchase intention at $<0.05$ significant level while entertainment has significant indirect effect on purchase intention at $<0.001$ significant level. Therefore H6 and $\mathrm{H} 7$ were supported.

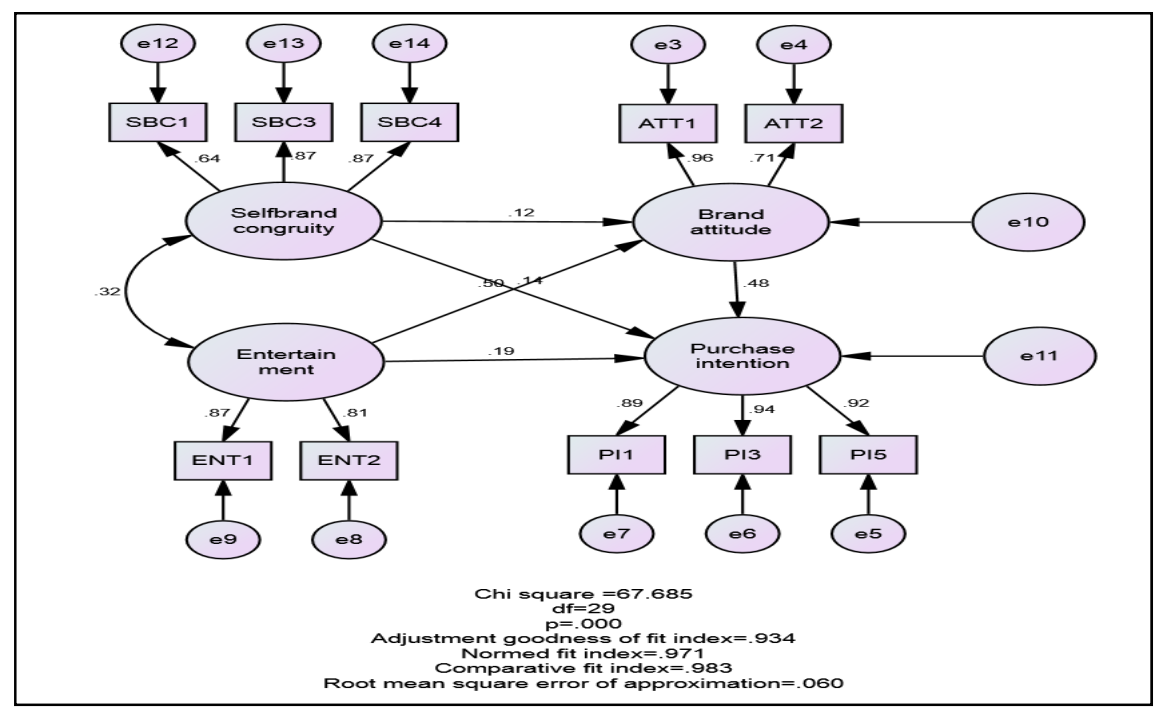

Figure 4. Results of Structural Model

Table 3. Results of hypotheses testing

\begin{tabular}{lll}
\hline & Estimate & Remarks \\
\hline H1: Self-brand congruity $\rightarrow$ brand attitude & $.202^{*}$ & Support hypothesis \\
H2: Self-brand congruity $\rightarrow$ purchase intention & $.207^{*}$ & Support hypothesis \\
H3: Entertainment $\rightarrow$ brand attitude & $.615^{* *}$ & Support hypothesis \\
H4: Entertainment $\rightarrow$ purchase intention & $.213^{* *}$ & Support hypothesis \\
H5: Brand attitude $\rightarrow$ purchase intention & $.433^{* * *}$ & Support hypothesis \\
\hline
\end{tabular}

$* * * \leq 0.001,{ }^{* *} \leq 0.01, * \leq 0.05$

Table 4. Results of bootstrap analysis of significance for brand attitude mediation effect

\begin{tabular}{lllll}
\hline & & Brand attitude & $\begin{array}{l}\text { Purchase } \\
\text { intention }\end{array}$ & Remarks \\
\hline Self-brand congruity & Direct effect & $\mathbf{. 0 3 0}$ & $\mathbf{. 0 0 5 * *}$ & Support hypothesis \\
& Indirect effect & $\ldots$ & $\mathbf{. 0 3 0}$ & \\
Entertainment & Direct effect & $\mathbf{. 0 0 1 * * *}$ & $\mathbf{. 0 0 3 * *}$ & Support hypothesis \\
& Indirect effect & $\ldots$ & $\mathbf{. 0 0 1 * * *}$ & \\
& & &
\end{tabular}

$* * * \leq 0.001, * * \leq 0.01, * \leq 0.05$ 


\section{Discussions}

This study attempts to investigate the effects of self-brand congruity and entertainment on brand attitude and purchase intention on Malaysian gamers. The results show that there is positive effect of self-brand congruity on brand attitude and purchase intention in advergames. A brand appearing in online games could be a popular or dominant brand from consumers' perspectives. When that particular brand matches their personality, it will influence the consumers' attitude towards the brand positively and ultimately will motivate their intention to purchase. This was supported by Escalas \& Bettman (2005) which suggested that the greater the congruity contributed to the positive brand attitude. Also, the level of brand association with the brand exposed in the game is considering "match" between the gamer's personality and the appeared brand and assist to purchase motivation. This view is consistent with Sirgy (1985) which suggested that self-congruity influence consumer's purchase intention.

This study also suggests that entertainment has positive effect on brand attitude and purchase intention. In the advergaming context, the entertainment value in advergames is important to determine the level of enjoyment and pleasure experienced by gamers during game-playing. The reason is that when the consumers are having fun in playing games, they could be able to recognize the brand that appears, which as a result motivates them to respond towards the brand positively due to their focus and excitement in accomplishing their gaming activity. The findings are consistent with previous studies which suggested that perceived entertainment had been identified as determinant influencing consumers' attitudes towards advertising in electronic commerce (Gao \& Koufaris, 2006; Brackett \& Carr, 2001) and as the main driver of brand attitude in advergames (Martí-Parreňo, Aldás-Manzano, Currás-Pérez, \& Sánchez-García, 2013).

The role of brand attitude in mediating the effects of self-brand congruity and entertainment, on purchase intention contributes interesting findings to the current research. As expected, brand attitude plays as an important role to become as mediator especially for the relationship between self-brand congruity and entertainment on purchase intention. Previous literature confirmed that brand attitude influenced purchase intention in marketing communication (MacKenzie et al., 1986). However, the effect of self-brand congruity on brand attitude is still less. As a result, this study contributes to the self-brand congruity-brand attitude relationship and also the mediating role of brand attitude towards purchase intention in advergame.

Besides that, this study also proposes that brand attitude mediates the relationship between entertainment factor and purchase intention. It confirmed that brand attitude mediates the relationship between entertainment and purchase intention in advergame.

\section{References}

Abdul Adis, A.-A., \& Kim, H.-J. (2013a). Antecedents of brand recall and brand attitude towards purchase intention in advergames. European Journal of Business and Management, 5(18), 58-67.

Abdul Adis, A.-A., \& Kim, H.-J. (2013b). The mediating role of brand recall and brand attitude in influencing purchase intention in advergames. Asia Marketing Journal, 15(3), 117-139.

Brackett, L., \& Carr, B. N. (2001). Cyberspace advertising vs. other media: Consumer vs. mature student attitudes. Journal of Advertising Research, 41(5), 23-32.

Cauberghe, V., \& Pelsmacker, P. D. (2010). The impact of brand prominence and game repetition on brand response. Journal of Advertising, 39(1), 5-18. http://dx.doi.org/10.2753/JOA0091-3367390101

Childers, T. L., Carr, C. L., Peck, J., \& Carson, S. (2001). Hedonic and utilitarian motivations for online shopping behaviour. Journal of Retailing, 77(4), 246-61. http://dx.doi.org/10.1016/S0022-4359(01)00056-2

Davis, R., \& Lang, B. (2013). Does game self-congruity increase usage and purchase? Young Consumers, 14(1), 52-66. http://dx.doi.org/10.1108/17473611311305485

Davis, R., Lang, B., \& Gautam, N. (2013). Modelling utilitarian-hedonic dual mediation (UHDM) in the purchase and use of games. Internet Research, 23(2), 229-256.

Dolich, I. J. (1969). Congruence relationships between self-images and product brands. Journal of Marketing Research, 6, 80-84. http://dx.doi.org/10.2307/3150001

Ducoffe, R. H. (1995). How consumers assess the value of advertising. Journal of Current Issues and Research in Advertising, 17(1), 1-18. http://dx.doi.org/10.1080/10641734.1995.10505022

Ducoffe, R. H. (1996). Advertising value and advertising on the web. Journal of Advertising Research, 36(5), 21-34. 
Escalas, J. E., \& Bettman, J. R. (2005). Self-construal, reference groups, and brand meaning. Journal of Consumer Research, 32, 378-389. http://dx.doi.org/10.1086/497549

Fiore, A., Jin, H., \& Kim, J. (2005). For fun and profit: Hedonic value from image interactivity and responses toward an online store. Psychology and Marketing, 22(8), 669-94. http://dx.doi.org/10.1002/mar.20079

Gao, Y., \& Koufaris, M. (2006). Perceptual antecedents of user attitude in electronic commerce. The DATA BASE for Advances in Information Systems, 37(2\&3), 42-50. http://dx.doi.org/10.1145/1161345.1161353

Gross, M. L. (2010). Advergames and the effects of game-product congruity. Computers in Human Behavior, 26, 1259-1265. http://dx.doi.org/10.1016/j.chb.2010.03.034

Hair, J. F., Black, W. C., Babin, B. J., Anderson, R. E., \& Tatham, R. L. (2006), Multivariate Data Analysis (6th ed.). Upper Saddle River, NJ: Pearson.

Hohenstein, N., Sirgy, M. J., Herrmann, A., \& Heitmann, M. (2007). Self-congruity: antecedents and consequences. In the proceedings of the Lalonde Conference (La Londe les Maures; June 5-8, 2007), edited by Soren Askedgaard, Dwight Merunka, and M. Joseph Sirgy, France; University Paul Cezanne Aix en Province, 118-130.

Huang, J., Su, S., Zou, L., \& Liu, X. (2013). Attitude toward the viral ad: Expanding traditional advertising models to interactive advertising. Journal of Interactive Marketing, 27, 36-46. http://dx.doi.org/10.1016/ j.intmar.2012.06.001

Kim, Y.-K., Sullivan, P., \& Forney, J. C. (2007). Experiential retailing: Concepts and strategies that Sell. Fairchild Publications, Inc. New York.

Lee, M., \& Faber, R. J. (2007). Effects of product placement in on-line games on brand memory. Journal of Advertising, 36(4), 75-90. http://dx.doi.org/10.2753/JOA0091-3367360406

Lui, F., Li, J., Mizerski, D., \& Soh, H. (2012). Self-congruity, brand attitude, and brand loyalty: A study on luxury brands. European Journal of Marketing, 46(7/8), 922-937. http://dx.doi.org/10.1108/ 03090561211230098

Lutz, R. J. (1977). An experiment investigation of causal relations among cognitions, affect and behaviourial intention. Journal of Consumer Research, 3(4), 197-208. http://dx.doi.org/10.1086/208668

Lutz, R. J., MacKenzie, S. B., \& Belch, G. E. (1983). Attitude toward the ad as a mediator of advertising effectiveness: Determinants and consequences. In R. P. Bagozzi, A. M. Tybout, \& A. Abor (Eds.), Advances in consumer research (Vol. 10, pp. 532-539). UT: Association for Consumer Research.

MacKenzie, S. B, Lutz, R. J., \& Belch, G. E. (1986). The role of attitude toward the ad as a mediator of advertising effectiveness: A test of competing explanations. Journal of Marketing Research, 23, 130-143. http://dx.doi.org/10.2307/3151660

Mangalindan, M., Swisher, K., Bank, D., Hamilton, D. P., \& Clark, D. (2004). Starting to click: after wave of disappointments, the web lures back advertisers; new generation of pitches nets data on consumers; not a mass audience; getting drivers to showroom. Wall Street Journal Eastern edition, February 9, R.3.

Martí-Parreňo, J., Aldás-Manzano, J., Currás-Pérez, R., \& Sánchez-García, I. (2013). Factors contributing brand attitude in advergames: Entertainment and irritation. Journal of Brand Management, 20(5), 374-388. http://dx.doi.org/10.1057/bm.2012.22

Nelson, M. R. (2002). Recall of brand placements in computer/video games. Journal of Advertising Research, 42(2), 80-92.

Nelson, M. R., Keum, H., \& Yaros, R. A. (2004). Advertainment or adcreep? Game players' attitudes toward advertising and product placements in computer games. Journal of Interactive Advertising, 5(1), 3-30. http://dx.doi.org/10.1080/15252019.2004.10722090

Percy, L., \& Rossiter, J. R. (1992). A model of brand awareness and brand attitude advertising strategies. Psychology \& Marketing, 9(4), 263-274. http://dx.doi.org/10.1002/mar.4220090402

Scarpi, D. (2012). Work and fun on the internet: The effects of utilitarianism and hedonism online. Journal of Interactive Marketing, 26(1), 53-67. http://dx.doi.org/10.1016/j.intmar.2011.08.001

Shah, S. S. H., Aziz, J., Jaffari, A. R., Waris, S., Ejaz, W., Fatima, M., \& Sherazi, S. K. (2012). The impact of brands on consumer purchase intentions. Asian Journal of Business Management, 4(2), 105-110.

Shwu-Lng, W., \& Chen-Lien, L. (2009). The influence of core brand attitude and core brand perception on 
purchase intention towards extended product. Journal of Marketing Logistics, 21(1), 174-194. http://dx.doi.org/10.1108/13555850910926317

Sirgy, M. J. (1985). Self-image/product-image congruity and consumer decision-making. International Journal of Management, 2, 49-63.

Sirgy, M. J., Lee, D. J., Johar, J. S., \& Tidwell, J. (2008). Effect of self-congruity with sponsorship on brand loyalty. Journal of Business Research, 61, 1091-1097. http://dx.doi.org/10.1016/j.jbusres.2007.09.022

Sirgy, M. J., Grewal, D., \& Mangleburg, T. (2000). Retail environment, self-congruity, and retail patronage: An integrative model and research agenda. Journal of Business Research, 49, 127-138. http://dx.doi.org/10.1016/S0148-2963(99)00009-0

Sirgy, M. J., \& Su, C. (2000). Destination image, self-congruity, and travel behavior: Toward an integrative model. Journal of Travel Research, 38, 340-352. http://dx.doi.org/10.1177/004728750003800402

Taylor, C. R. (2009). The six principles of digital advertising. International Journal of Advertising, 28(3), 411-418. http://dx.doi.org/10.2501/S0265048709200679

Teng, L. L. M., \& Huihuang, Z. (2007). The effects of multiple-ads and multiple-brandson consumer attitude and purchase behaviour. Journal of Consumer Marketing, 24(1), 27-35. http://dx.doi.org/10.1108/ 07363760710720966

Wise, K., Bolls, P. D., Kim, H., Venkataraman, A., \& Meyer, R. (2008). Enjoyment of advergames and brand attitudes: The impact of thematic relevance. Journal of Interactive Advertising, 9(1), 27-36. http://dx.doi.org/10.1108/07363760710720966

Zarantonello, L., \& Schmitt, B. (2012). The impact of event marketing on brand equity: The mediating roles of brand experience and brand attitude. International Journal of Advertising. Retrieved from http://ssrn.com/abstract=2175793

\section{Copyrights}

Copyright for this article is retained by the author(s), with first publication rights granted to the journal.

This is an open-access article distributed under the terms and conditions of the Creative Commons Attribution license (http://creativecommons.org/licenses/by/3.0/). 